\title{
STUDI RETROSPEKTIF PERBANDINGAN EFEKTIVITAS TETES MATA DENGAN DEKSAMETASON DAN TANPA DEKSAMETASON DALAM MENGATASI KONJUNGTIVITIS
}

\author{
(A RETROSPECTIVE STUDY OF THE EFFECTIVENESS COMPARISON OF OPHTALMIC \\ SOLUTION WITH AND WITHOUT DEXAMETHASONE IN CONJUNCTIVITIS TREATMENT)
}

\author{
HERLEEYANA MERIYANI*; NI WAYAN CIPTAWATI* ${ }^{*}$ NI NYOMAN WAHYU UDAYANI* \\ ${ }^{*}$ Program Studi D3 Farmasi, Fakultas Farmasi Universitas Mahasaraswati Denpasar, \\ Jalan Kamboja No.11A, Denpasar, Bali
}

\begin{abstract}
Abstrak: Konjungtivitis adalah inflamasi yang terjadi pada konjungtiva yang secara umum dapat disebabkan oleh infeksi (bakteri, virus), gangguan system imun, gangguan mekanik, maupun neoplastic. Saat ini konjungtivitis masih menjadi masalah kesehatan mata di Indonesia. Penelitian ini bertujuan untuk membandingkan waktu sembuh 2 sediaan yang sudah sering digunakan di Indonesia, dimana sediaan pertama mengandung Neomycin sulphate polymixin B sulphate dan gramicidin dan sediaan kedua mengandung Neomycin sulphate, Polymyxin B sulphate dan dexamethasone dalam mengatasi konjungtivitis. Penelitian ini merupakan penelitian non eksperimental yaitu Cross Sectional dengan pengambilan data secara retrospektif di salah satu rumah sakit pemerintah di Bali. Sample diambil dengan teknik purposive sampling dan pengambilan data dilakukan menggunakan data sekunder yaitu catatan rekam medis. Subjek dalam penelitian ini sebanyak 56 orang yang terdiri atas $53,57 \%$ laki-laki dan $46,43 \%$ perempuan. Dilihat dari usia subjek terbanyak ada pada rentang usia 17-30 tahun (28,60\%), mayoritas subjek menderita konjungtivitis di salah satu mata sebanyak 51,8\%. Berdasarkan hasil penelitian diperoleh bahwa penggunaan penggunaan sediaan yang mengandung Neomycin sulphate, Polymyxin B sulphate dan dexamethasone memiliki waktu sembuh yang lebih cepat dibandingkan dengan Neomycin sulphate polymixin B sulphate dan gramicidin $(\mathrm{p}<0,05)$. Berdasarkan hasil penelitian dapat disimpulkan bahwa penggunaan tetes mata antibiotic dikombinasi dengan dexamethasone lebih efektif untuk mengatasi konjungtivitis dibandingkan dengan tetes mata tanpa dexamethasone dilihat dari waktu sembuh.
\end{abstract}

Kata Kunci: antibiotik, dexamethasone, konjungtivitis

\begin{abstract}
Conjunctivitis is inflammation that occurs in the conjunctiva which can generally be caused by infections (bacteria, viruses), immune system disorders, mechanical disorders, or neoplastic. At present conjunctivitis is still an eye health problem in Indonesia. This study aims to compare the recovery time of 2 preparations that are often used in Indonesia, the first preparation contains Neomycin sulphate polymixin B sulphate and gramicidin and the second preparation contains Neomycin sulphate, Polymyxin B sulphate and dexamethasone in dealing with conjunctivitis. This research is a non-experimental research that is Cross Sectional with retrospective data collection at one of the public hospitals in Bali. Samples were taken with a purposive sampling technique and data collection was performed using medical records. The subjects in this study were 56 people consisting of $53.57 \%$ men and $46.43 \%$ women. Judging from the age of most subjects in the age range of $17-30$ years $(28.60 \%)$, the majority of subjects suffered from conjunctivitis in one eye as much as $51.8 \%$. Based on the results of the study, it was obtained that the use of preparations containing Neomycin sulphate, Polymyxin B sulphate and dexamethasone had faster recovery time compared to Neomycin sulphate polymixin B sulphate and gramicidin $(\mathrm{p}<0.05)$. Based on the results of the study it can be concluded that the use of antibiotic eye drops combined with dexamethasone is more effective to treat conjunctivitis compared to eye drops without dexamethasone based on the time of recovery parameter.
\end{abstract}

Keywords: conjunctivitis, antibiotics, dexamethasone

• correspondence email: ching25.lee@gmail.com 


\section{PENDAHULUAN}

Menurut American Academy of Ophtalmology (2013), konjungtivitis adalah inflamasi yang terjadi pada konjungtiva yang secara umum dapat disebabkan oleh infeksi (bakteri, virus), gangguan system imun, gangguan mekanik, maupun neoplastic. Konjungtivitis secara umum dibagi menjadi konjungtivitis infeksius dan non infeksius, sedangkan berdasarkan waktu dapat dibagi menjadi konjungtivitis akut dan kronis. Pada konjungtivitis infeksi, penyebab tersering adalah virus dan bakteri, sedangkan pada kelompok noninfeksi disebabkan oleh alergi, reaksi toksik, dan inflamasi sekunder lainnya. Pada kondisi akut, gejala terjadi hingga empat minggu, sedangkan pada konjungtivitis kronik, gejala lebih dari empat minggu. Konjungtivitis merupakan self- limiting disease namun pada kondisi tertentu dapat menimbulkan kompikasi ocular dan ekstraokular apabila tidak tertangani dengan baik (American Optometric Association, 2002; American Academy of Ophtalmology, 2013; Sitompul, 2017; Kovalyuk et al, 2017).

Pada populasi dewasa, $80 \%$ konjungtivitis akut di sebabkan oleh bakteri, virus dan alergi dengan gejala ringan tanpa disertai penurunan ketajaman pengelihatan, meskipun demikian terdapat kasus yang dapat mengancam pengelihatan sehingga perlu segera dirujuk ke dokter spesialis mata untuk tata laksana lebih lanjut (Hovding, 2008). Di Indonesia, penyakit ini masih banyak terdapat dan paling sering dihubungkan dengan kondisi lingkungan yang tidak hygiene (Erwin, 2012). Hyegine adalah suatu usaha pencegahan penyakit yang menitik beratkan pada usaha kesehatan perorangan atau manusia beserta lingkungan tempat orang tersebut berada (Widyati, 2002. Retno, 2002 dan Yuliar, 2002). Dari insidensi konjungtivitis di Indonesia saat ini menduduki $9.7 \%$ dari 10 penyakit utama, (Chiang et al, 2012). Di Rumah Sakit Mata di bali, konjungtivitis masih termasuk dalam 10 besar penyakit mata.

Penggunaan tetes mata antibiotic dalam terapi empiric untuk mengatasi konjungtivitis memberikan hasil yang baik (American Academy of Ophtalmology, 2013). Di Indonesia sendiri terapi konjungtivitis diberikan seiaan topical antibiotic. Antibiotik yang digunakan merupakan antibiotic kombinasi yang merupakan golongan aminoglikosida. Pada penelitian ini akan dibandingkan efektivitas terapi 2 sediaan ophthalmic yang beredar di Indonesia. Sediaan pertama setiap mili liter terdiri atas kombinasi Neomycin sulphate setara neomycin base $1.5 \mathrm{mg}$, polymixin B sulphate 10.000 UI dan gramicidin $0.025 \mathrm{mg}$. sediaan kedua setiap mili liter mengandung Dexamethasone $1 \mathrm{mg}$, Neomycin sulphate $3.5 \mathrm{mg}$, Polymyxin B sulphate $10.000 \mathrm{UI}$. Penelitian ini bertujuan untuk membandingkan efektivitas dua sediaan tersebut dalam mengatasi konjungtivitis dilihat dari parameter waktu kesembuhan.

\section{METODE PENELITIAN}

Instrumen Penelitian. Penelitian ini menggunakan data rekam medis di unit rekam medis Rumah sakit mata yang terletak di Provinsi Bali.

Rancangan Penelitian. Penelitian ini merupakan penelitian non ekperimental crossectional dengan pengumpulan data secara retrospektif. Adapun sediaan yang dibandingkan yaitu:

a. Sediaan pertama setiap mililiter terdiri atas kombinasi Neomycin sulphate setara neomycin base $1.5 \mathrm{mg}$, polymixin B sulphate $10.000 \mathrm{UI}$ dan gramicidin $0.025 \mathrm{mg}$.

b. Sediaan kedua setiap mili liter mengandung Dexamethasone $1 \mathrm{mg}$, Neomycin sulphate 3.5 mg, Polymyxin B sulphate 10.000 UI.

Untuk menilai efektivitas terapi dilakukan dengan membandingkan waktu sembuh masing-masing sediaan.

Kriteria inklusi:

a. Semua pasien dewasa yang menderita konjungtivitis usia 17-60 tahun

b. Pasien yang berobat selama periode 2019 .

Kriteria eksklusi:

a. Pasien dengan data yang tidak lengkap

b. Pasien yang tidak kembali lahi setelah pengobatan selesai

\section{HASIL DAN PEMBAHASAN}

Dalam penelitian ini besar sampel yang digunakan dalam penelitian yaitu 56 pasien. Masing-masing kelompok berjumlah 28 orang. Adapun karakteristik pasien berdasarkan jenis kelamin dapat dilihat pada tabel 1, dan karakteristik pasien berdasarkan usia dapat dilihat pada tabel 2 . Berdasarkan tabel 1 dapat dilihat bahwa wanita lebih banyak menderita konjungtivitis dari pada pria. 
Tabel 1. Karakteristik pasien konjungtivitis berdasarkan jenis kelamin

\begin{tabular}{ccc}
\hline $\begin{array}{c}\text { Jenis } \\
\text { kelamin }\end{array}$ & Jumlah & $\begin{array}{c}\text { Persentase } \\
(\mathbf{\%})\end{array}$ \\
\hline Laki-laki & 30 Orang & $53.57 \%$ \\
Perempuan & 26 Orang & $46.43 \%$ \\
Jumlah & 56 Orang & $100,00 \%$ \\
\hline
\end{tabular}

Berdasarkan tabel 2 diketahui bahwa pasien dengan konjungtivitis paling banyak terdapat pada pasien berusia antara 17-30 tahun. Hal ini sesuai dengan penelitian yang dilakukan oleh Azari et al (2013), konjungtivitis cenderung menyerang pasien dengan usia yang lebih muda. Usia yang lebih muda cenderung lebih aktif dalam beraktivitas dibandingkan dengan yang usia tua, meskipun demikian selain factor usia masih banyak factor lain yang mengakibatkan seseorang berisiko untuk mengalami konjungtivitis seperti kondisi di musim semi dan musim panas, faktor lingkungan, dan faktor hygiene.

Tabel 2. Karakteristik pasien konjungtivitis berdasarkan usia pasien

\begin{tabular}{ccc}
\hline Umur & Jumlah & $\begin{array}{c}\text { Persentase } \\
(\boldsymbol{\%})\end{array}$ \\
\hline 17-30 tahun & 16 orang & $28,60 \%$ \\
31-40 tahun & 14 orang & $25,00 \%$ \\
41-50 tahun & 14 orang & $25,00 \%$ \\
51-60 tahun & 12 orang & $21,40 \%$ \\
Jumlah & 56 orang & $100,00 \%$ \\
\hline
\end{tabular}

Karakteristik pasien berdasarkan lokasi infeksi dapat dilihat pada tabel 3. Berdasarkan lokasi infeksi dapat dilihat bahwa infeksi pada salah satu mata lebih banyak terjadi dibandingkan dengan infeksi pada kedua mata.

Tabel 3. Karakteristik pasien konjungtivitis berdasarkan lokasi terinfeksi

\begin{tabular}{ccc}
\hline $\begin{array}{c}\text { Lokasi } \\
\text { terinfeksi }\end{array}$ & Jumlah & Persentase(\%) \\
\hline OD & 17 & $30,4 \%$ \\
OS & 12 & $21,4 \%$ \\
ODS & 27 & $48,2 \%$ \\
Jumlah & 56 & $100 \%$ \\
\hline Keterangan: \\
OD = Oculus Dextra = Mata kanan \\
OS = Oculus Sinestra = Mata kiri \\
ODS = Oculus Dextra et Sinestra = Mata kanan dan kiri
\end{tabular}

Dasar dari pengobatan konjungtivitis adalah meningkatkan kenyamanan pasien, mengatasi infeksi, mencegah penyebaran infeksi. Antibiotic yang dipilih untuk mengatasi konjungtivitis adalah antibiotic spectrum luas yang diberikan secara topical. Beberapa antibiotic yang dapat digunakan untuk mengatasi konjungtivitis adalah golongan aminoglikosida, fluorokuinolon, dan polymyxin/ bacitracin (Sheikh and Hurwitz, 2001; Azari et al, 2013). Terapi steroid topical tidak disarankan pada pasien konjungtivitis karena tingginya risiko potensi lamanya waktu yang dibutuhkan untuk sembuh bahkan meningkatkan potensi infeksi (Quinn, 2002; Azari et al, 2013).

Berdasarkan hasil uji Mann Whitney (Tabel 4) diketahui bahwa pasien yang menggunakan obat yang mengandung dexamethasone memiliki waktu sembuh yang lebih cepat dibandingkan dengan sediaan yang antibiotic tanpa dexamethasone $(\mathrm{p}<0,05)$.

Tabel 4. Hasil uji Mann Whitney perbandingan waktu kesembuhan tiap kelompok

\begin{tabular}{cccc}
\hline $\begin{array}{c}\text { Obat yang } \\
\text { digunakan }\end{array}$ & $\mathbf{n}$ & $\begin{array}{c}\text { Median } \\
\text { (minimum - } \\
\text { maksimum) }\end{array}$ & $\mathbf{p}$ \\
\hline $\begin{array}{c}\text { Polymixin-B, } \\
\text { Niomicin } \\
\text { sulphate, }\end{array}$ & 28 & $14(14-21)$ & \\
Gramycidin & & & 0,0001 \\
$\begin{array}{c}\text { Polymixin-B } \\
\text { Sulphate, } \\
\text { Niomicin } \\
\text { sulphate, }\end{array}$ & 28 & $7(7-14)$ & \\
Dexamethason & & & \\
\hline
\end{tabular}

Penggunaan dexamethasone untuk mengatasi konjungtivitis masih menjadi perdebatan. Beberapa penelitian menyarankan sebaiknya tidak menggunakan kotrikosteroid topical karena adanya risiko pritensi lamanya waktu yang dibutuhkan untuk sembuh bahkan meningkatkan potensi infeksi (Quinn, 2002; Azari et al, 2013). Penggunaan kortikosteroid topical diabsorpsi dengan baik di kornea, konjungtiva dan sklera setelah pemberian tetes mata. Steroid memberikan efek yang baik pada konjungtivitis akibat gangguan mekanis (seperti trauma), abnormalitas system imun (immunoreactivity) atau kombinasi antara gangguan imun dan infeksi. Akan tetapi penggunaan steroid topical pada keratitis bacterial dapat mengakibatkan kegagalan fungsi neutrophil dan mempengaruhi flora normal konjungtiva (Ernis et al, 2004).

Bertentangan dengan penelitian sebelumnya, penelitian yang dilakukan oleh Holland et al tahun 2017, penggunaan kortikosteroid pada kasus konjungtivitis dapat mengurangi inflamasi ocular yang terjadi, namun 
sebaiknya tidak digunakan jangka panjang. Penggunaan kortikosteroid ophthalmic jangka panjang mengarah pada timbulnya infeksi skunder. Oenggunaan tetes mata kortikosteroid disarankan tidak lebih dari 7 hari.

Selain regimen tetes mata pada penelitian ini juga dilihat perbedaan lama kesembuhan berdasrkan jenis kelamin, usia dan lokasi infeksi. Berdasarkan hasil uji Mann Whitney diketahui bahwa tidak terdapat perbedaan yang bermakna antara waktu sembuh kelompok laki-laki dan perempuan, usia dan lokasi infeksi $(\mathrm{p}<0,05)$ (Tabel $5)$.

Tabel 5. Perbandingan waktu sembuh berdasarkan jenis kelamin, usia dan lokasi infeksi

\begin{tabular}{|c|c|c|c|c|}
\hline NO & Keterangan & $\mathbf{n}$ & Mean & $\mathbf{p}$ \\
\hline \multicolumn{5}{|c|}{ Jenis kelamin } \\
\hline 1 & Laki laki & 30 & 12,83 & \multirow{2}{*}{0,762} \\
\hline & Perempuan & 26 & 12,38 & \\
\hline \multicolumn{5}{|l|}{ Usia } \\
\hline 2 & $\begin{array}{l}<40 \text { tahun } \\
\geq 40 \text { tahun }\end{array}$ & $\begin{array}{l}30 \\
26\end{array}$ & $\begin{array}{l}13,30 \\
11,84\end{array}$ & 0,262 \\
\hline \multicolumn{5}{|c|}{ Lokasi infeksi } \\
\hline 3 & $\begin{array}{l}\text { Salah satu mata } \\
\text { Kedua mata }\end{array}$ & $\begin{array}{l}29 \\
27\end{array}$ & $\begin{array}{l}13,52 \\
11,67\end{array}$ & 0,183 \\
\hline
\end{tabular}

Berdasarkan tabel 5 dapat dilihat bahwa waktu sembuh tidak dipengaruhi oleh jenis kelamin, usia maupun lokasi infeksi. Menurut penelitian yang dilakukan oleh Azari et al (2013), konjungtivitis cenderung menyerang pasien dengan usia yang lebih muda.

\section{SIMPULAN}

Berdasarkan hasil penelitian dapat disimpulkan bahwa penggunaan tetes mata antibiotik dikombinasi dengan dexamethasone lebih efektif untuk mengatasi konjungtivitis dibandingkan dengan tetes mata tanpa dexamethasone dilihat dari waktu sembuh.

\section{DAFTAR PUSTAKA}

Azari, A.A. and Barney, N.P., 2013. Conjunctivitis: a systematic review of diagnosis and treatment. Jama, 310(16), pp.1721-1730.

American Optometric Association, 2002. Care of the patient with conjunctivitis. St Louis: American Optometric Association.

Chiang CC, Liao CC, Chen PC, Tsai YY, Wang YP, Population study on Chronic and acute conjungtivitis associated with ambient environment in urban and rural areas. J Expo Sci Environ Epidemiol 2012;22(5);533-538.

Ermis, S.S., Aktepe, O.C., Inan, U.U., Ozturk, F. and Altindis, M., 2004. Effect of topical dexamethasone and ciprofloxacin on bacterial flora of healthy conjunctiva. Eye, 18(3), pp.249252.

Holland, E.J., Fingeret, M. and Mah, F.S., 2019. Use of topical steroids in conjunctivitis: a review of the evidence. Cornea, 38(8), pp.1062-1067.

Høvding, G., 2008. Acute bacterial conjunctivitis. Acta ophthalmologica, 86(1), pp.5-17.

Kovalyuk, N., Kaiserman, I., Mimouni, M., Cohen, O., Levartovsky, S., Sherbany, H. and Mandelboim, M., 2017. Treatment of adenoviral keratoconjunctivitis with a combination of povidone-iodine $1.0 \%$ and dexamethasone $0.1 \%$ drops: a clinical prospective controlled randomized study. Acta ophthalmologica, 95(8), pp.e686e692.

Sitompul, R., 2017. Konjungtivitis Viral: Diagnosis dan Terapi di Pelayanan Kesehatan Primer. eJournal Kedokteran Indonesia, 5(1). 
HERLEEYANA MERIYANI. Jurnal IImiah Medicamento 6(1), 40-44

Sheikh, A. and Hurwitz, B., 2005. Topical antibiotics for acute bacterial conjunctivitis: Cochrane systematic review and meta-analysis update. Br J Gen Pract, 55(521), pp.962-964. 